\title{
Staining fungal structures with artificial dyes used in the industry of juices
}

\author{
Jeniffer Keterly Gonçalves Santana ${ }^{1} \odot$ André Leal Seixas $^{1}$ Lucas Henrique Gonçalves Ribeiro ${ }^{1}$ \\ Ana Clara Santos Cardoso ${ }^{1}$ Fernando da Silva Rocha $^{2 *} \odot$ \\ Maria de Fátima Gonçalves Fernandes ${ }^{2}$ - Maria de Fátima Silva Muniz ${ }^{3}$
}

${ }^{1}$ Instituto Federal do Norte de Minas Gerais (IFNMG), Montes Claros, MG, Brasil.

${ }^{2}$ Universidade Federal de Minas Gerais (UFMG), 39404-547, Montes Claros, MG, Brasil. E-mail: rochafsplant@yahoo.com.br. "Corresponding author. ${ }^{3}$ Centro de Ciências Agrárias, Universidade Federal de Alagoas (UFAL), Rio Largo, AL, Brasil.

ABSTRACT: The objective of this research was to evaluate the efficiency of artificial dyes, sunset yellow and red bordeaux $S$, and the use of glycerol in different concentrations to consistently stain fungal structures in slides containing spores of Oidium sp., Albugo ipomoeaepanduratae, Pochonia chlamydosporia and hyphae of Phytopythium helicoides. Commercial product mixtures of the artificial dyes at 0.5, 1.0, $1.5,2.0,3.0$ and $5.0 \%(w / v)$ added with glycerol at $0.25,0.5$ and $1.0 \%$ were evaluated. To stain chlamydospores, the suspension was placed in the staining solution or heated at $80^{\circ} \mathrm{C}$ for 5 minutes. The slides were prepared by the wet mount slide method. Fungal spores were consistently stained starting at a concentration of $2 \%$ of the staining solution. The addition of glycerol to the staining solution improved the contrast of the sporangia, hyphae and chlamydospores. Higher intensity and uniformity of chlamydospore's staining was verified using $3 \%$ dye solution and $1 \%$ heated glycerol, when compared to the unheated and blue-cotton solution.

Key words: sunset yellow, red bordeaux, azo dyes, fungal staining.

\section{Coloração de estruturas de fungos com corantes artificiais usados na fabricação de sucos}

RESUMO: Neste trabalho, objetivou-se avaliar a eficiência dos corantes artificiais, amarelo crepúsculo e vermelho bordeaux $S$, e o uso do glicerol em diferentes concentrações, na montagem de lâminas com esporos de Oidium sp., Albugo ipomoeae-panduratae, Pochonia chlamydosporia e hifas de Phytopythium helicoides. Foram avaliadas as concentrações de 0,5, 1,0, 1,5, 2,0, 3,0 e 5,0\% (p/v) do produto comercial da mistura dos corantes artificiais e adição de glicerol nas concentrações de 0,25, 0,5 e 1,0\%. Para coloração de clamidósporos, a suspensão foi colocada na solução corante ou aquecida a $80^{\circ} \mathrm{C}$ por 5 minutos e as lâminas preparadas com líquido de montagem. A partir da concentração de $2 \%$ da mistura dos corantes houve maior coloração dos esporos. A adição de glicerol na solução corante melhorou o contraste dos esporângios, hifas e clamidósporos. Maior intensidade e uniformidade de coloração de clamidósporos ocorreram na solução corante 3\% e glicerol 1\% aquecida, em comparação com a solução sem aquecimento e azul-de-algodão.

Palavras-chave: amarelo crepúsculo, vermelho bordeaux, corantes azo, coloração fúngica.

Phytopathology laboratories regularly prepare microscope slides in order to observe and identify reproductive and/or vegetative structures from plant pathogenic fungi and those used in biological control. Cotton blue (methylene blue) and Trypan Blue are the most commonly used dyes in the preparation of temporary slides for phytopathological studies (MAFIA \& ALFENAS, 2016). Lactophenol Cotton Blue (LPCB) is the most commonly used mounting fluid for preparation of microscopy slides. Phenol is the main component of LPCB, being well known as a mutagenic, tumorigenic and toxic to man and the environment (IPCS, 2017). BASAVA et al. (2016) demonstrated that Iodine-glycerol has great potential to replace LPCB as a slide mounting liquid.
Another alternative dye, phloxine B is used in the study of basiodiomycotina (RYVARDEN, 1991). However, phloxine $\mathrm{B}$ is harmful to the user and the environment and requires costly procedures for waste disposal, whereas Iodine-glycerol is known to be a hazardous substance, and moreover, both dyes are difficult to acquire and also more expensive than azo dyes in the Brazilian market.

In Brazil, the Ministry of Health, through the Agência Nacional de Vigilância SanitáriaANVISA, allows the use of azo dyes in the food industry for coloring foodstuff and juices. Azo dyes are the main group of synthetic pigments in the world and widely used in the industry (SINGH et al., 2015, CHUNG, 2016). ROCHA et al. (2005) 
studied the efficiency of azo dyes for staining phytonematodes and found that dyes containing bordeaux, red bordeaux, and the mixture of bordeaux and $1 \%$ indigotine blue, consistently stained in red color the egg masses, eggs, juveniles and females of Meloidogyne incognita, inside the root, compared to the dyes phloxine B and acid fuchsin. However, studies regarding the use of artificial dyes for staining fungal structures are scarce. The objective of this work was to evaluate the efficiency of artificial dyes, used in the industry of juices, at different concentrations or in mixture with glycerol for staining some hyaline, reproductive or vegetative structures, useful for the identification of Oidium sp., Albugo ipomoeaepanduratae (pathogenic fungi in several crops), Pochonia chlamydosporia (nematophagous fungus) and Phytopythium helicoides (important soilborne oomycete that causes damping-off).

The commercial product Docile ${ }^{\circledR}$, strawberry flavor, was used to prepare solutions containing the artificial dyes sunset yellow and bordeaux S. Solutions were prepared in distilled water at concentrations of $0.5,1.0,1.5,2,3$ and $5 \%$ $(\mathrm{w} / \mathrm{v})$. These solutions were used as a mounting liquid for the staining of fungal structures. The first assay was performed to determine the best concentration of the dyes for spore staining (SANTANA et al., 2017). In this study powdery mildew (Oidium sp.) samples obtained from leaves of Peplonia axillaris were used. Spores were collected from the leaf lesions by scraping and the slides were mounted by the wet mount slide method with the staining solutions at different concentrations. The slides were covered with glass coverslips. Slides mounted with the cottonblue dye were used as reference standard (control). Photographs of the spores were obtained with a light microscope at $40 \mathrm{X}$ magnification and a 13 megapixel camera. In the second assay, the effect of adding glycerol at concentrations of $0.25,0.5$ and $1.0 \%$ (w/ v) into the staining solutions (1,3 and 5\%) for staining sporangium of $A$. ipomoeae-panduratae, hyphae of $P$. helicoides and chlamydospores of $P$. chlamydosporia, was studied. The addition of glycerol in the staining solution was based on previous studies reporting better visualization of the fungal structures on slides (VIGNESH et al., 2013). Leaves of Ipomoea batatas with symptoms of white rust (A. ipomoeaepanduratae) and an isolate of $P$. helicoides obtained from lettuce seedlings were used to mount the slides for staining the sporangia and hyphae, respectively. For staining chlamydospores, the commercial product Rizotec $\left(5.2 \times 10^{7}\right.$ chlamydospores/g), formulated with $P$. chlamydosporia var. chlamydosporia isolate
Pc-10, was used. The chlamydospores were obtained according to the technique of COOLEN \& D'HERDE (1972) with modifications (rotation 1,000rpm for 2 minutes) and placed in test tubes containing the staining solutions or heated at $80^{\circ} \mathrm{C}$ for 5 minutes, followed by assembly of the slides and acquisition of the images.

Slides mounted with cotton-blue dye stained the spores of Oidium sp. in blue and those with the artificial dyes sunset yellow and red bordeaux $\mathrm{S}$ stained the spores with color intensity varying from orange red to magenta (Figures 1A-G). The increasing concentration of the dyes provided greater contrast in the color of Oidium sp. spores. Starting at a concentration of $2 \%$, a stronger staining intensity of the fungal spores was observed when compared to the cotton-blue dye. The strongest color intensity was observed in spores of Oidium sp. stained with the dyes at $5 \%$ concentration (Figure $1 \mathrm{G}$ ). The results of the staining intensity of $A$. ipomoeae-panduratae sporangia were similar to those of Oidium sp. (Figures 1I, J and K). The addition of glycerol in the staining solutions did not interfere with the intensity of sporangia staining but resulted in a higher contrast when compared to those stained only with the staining solution and cotton blue (Figures 1H, L, M and N).

In previous studies performed in our laboratory we also observed a similar result while staining hyphae, sporangiophores and sporangia of $P$. helicoides (SANTANA et al., 2017). In this work we observed the mixing of $2 \%$ concentration of both dyes (sunset yellow and red bordeaux) resulted in better staining and contrast of the fungal structures. However, in the present study we observed a higher contrast in the color intensity of $P$. helicoides hyphae using 3\% staining solution, however, when we added $1 \%$ glycerol to the $5 \%$ solution there was better sharpness when compared to cotton blue (Figures 1O, $\mathrm{P}$ and Q). Therefore, glycerol in addition to acting as a hygroscopic agent, avoiding desiccation and changes in the morphological structure of the fungal structures, also increases the longevity of the slide and the contrast of the fungal structure when observed under a light microscope. However, in this work we only evaluated the color intensity of the artificial dyes, color uniformity and their fixation to the fungal spores for two weeks. During this period it was observed a reduction in color intensity, but the contrast of fungal structures remained excellent. Chlamydospores of $P$. chlamydosporia showed higher intensity and color uniformity at $5 \%$ concentration of the staining solution heated with $1 \%$ glycerol, compared to the staining solution without 


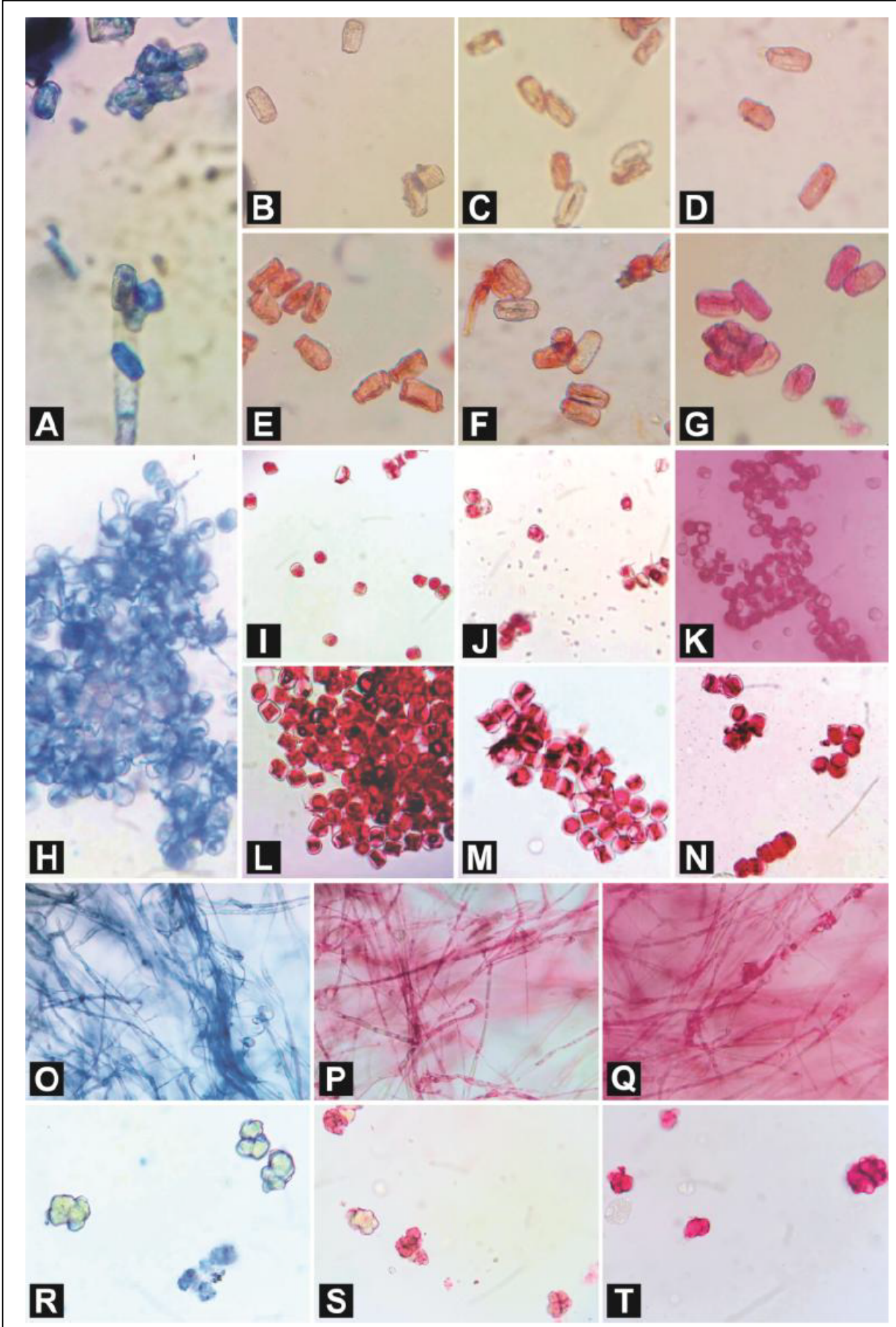

Figure 1 - Spores of Oidium sp. staining with cotton blue (A) and artificial dyes, sunset yellow and red bordeaux S, at concentration of $0.5(\mathrm{~B}), 1.0(\mathrm{C}), 1.5(\mathrm{D}), 2$ (E), 3 (F) and 5\% (G). H-K: Stained sporangia of Albugo ipomoeae-panduratae with standard dye and artificial dyes at different concentrations. H- Cotton blue. I- Dye solution at 1\%. J- Dye solution at 3\%. K- Dye solution at 5\%. L-N: Staining with 5\% dye solution and glycerol in different concentrations. L- Glycerol at $0.25 \%$. M- Glycerol at 0,5\%. N- Glycerol at 1,0\%. O-T: Staining of Phytopythium helicoides and chlamydospores of Phochonia chlamydosporia with standard dye and artificial dyes. O-Q: Staining of hyphae of $P$. helicoides. O- Cotton blue. P- Dye solution at 3\%. Q- Dye solution at $5 \%$ and glycerol at 1\%. R-T: Staining of chlamydospores of P. chlamydosporia. R- Cotton blue. S- Dye solution at $3 \%$. T- Dye solution at $5 \%$ and glycerol at $1 \%$. 
heating and the control (Figures 1R, S and T). At 3\% and lower concentration solutions, there was poor uniformity of coloration of the chlamydospores, especially in the staining solutions without heating. Heating the dye can accelerate the fixation reaction and/or increase the penetration of the dye in the thickwalled chlamydospore (BOEDIJN, 1956; EVANS \& KIRK, 2017). Sunset yellow and red bordeaux S (amaranth) are classified as azo dyes, since they are synthesized from various aromatic amines derived from tar (BAFANA et al., 2011; AL-RUBAIE \& MHESSN, 2012). Thus, as the dyes used in this study are water soluble, their use in the laboratory may be a safer alternative than the traditional LPCB in the preparation of temporary fungal slides. Although azo dyes, including sunset yellow and red bordeaux $\mathrm{S}$, are used in the food industry in Brazil, these dyes exhibit certain toxicity, but their use in the staining of microscopic samples causes less health problems and environmental risks compared to LPCB. Furthermore, azo dyes are cheaper making them of great utility for routine utilization in mycological studies.

\section{ACKNOWLEDGEMENTS}

The first two authors thank Universidade Federal de Minas Gerais (UFMG) and Fundação de Amparo à Pesquisa do Estado de Minas Gerais (FAPEMIG) for the scholarship and the opportunity to carry out this research.

\section{CONFLICTS OF INTEREST}

The authors declare no conflict of interest. The founding sponsors had no role in the design of the study; in the collection, analyses, or interpretation of data; in the writing of the manuscript, and in the decision to publish the results.

\section{REFERENCES}

AL-RUBAIE, L.A.R.; MHESSN, R.J. Synthesis and characterization of azo dye para red and new derivatives. E-Journal of Chemistry, v.9, p.465-470, 2012. Available from: $<$ http://scihub.tw/https://www.hindawi.com/journals/jchem/2012/206076/ abs/>. Accessed: Feb. 2, 2016. doi: 10.1155/2012/206076.

BAFANA, A. et al. Azo dyes: past, present and the future. Environmental Reviews, v.19, p.350-370, 2011. Available from: $<$ https://doi.org/10.1139/a11-018>. Accessed: Jun. 7, 2016. doi: 10.1139/a11-018.

BASAVA, S.P.R. et al. Efficacy of iodine-glycerol versus lactophenol cotton blue for identification of fungal elements in the clinical laboratory. International Journal of Current Microbiology and Applied Sciences, v.5, p.536-541, 2016. Available from: <http:// dx.doi.org/10.20546/ijcmas.2016.511.063>. Accessed: Jun. 7, 2016. doi: 10.20546/ijcmas.2016.511.063.

BOEDIJN, K. B. Trypan blue as a stain for fungi. Stain Technology, v.31,p.115-116, 1956.

CHUNG, K.T. Azo dyes and human health: a review. Journal of Environmental Science and Health, v. 34, p.233-261, 2016. Available from: <https://sci-hub.tw/10.10 80/10590501.2016.1236602.> Accessed: Jun. 7, 2016. doi: 10.1080/10590501.2016.1236602.

COOLEN, W.A.; D'HERDE, C.J. A method for the quantitative extraction of nematodes from plant tissue culture. Ghent: State Agriculture Research Centre, 1972. 77p.

EVANS, H.C.; KIRK, P.M. Systematics of Pochonia. In: MANZANILLA-LÓPEZ, R.H.; LOPES-LLORCA, L.V. Perspectives in sustainable nematode management through Pochonia chlamysdosporia applications for root and rhizosphere health. Cham, Switzerland: Springer International Publishing, 2017. p.21-43.

IPCS. Phenol: health and safety guide. Geneva: WHO, 1994. Available from: <http://inchem.org/documents/hsg/hsg/hsg88_e. htm>. Accessed: Nov. 7, 2017.

MAFIA, R.G.; ALFENAS, A.C. Preparações e observações microscópicas de espécimes fúngicas. In: ALFENAS, A.C.; MAFIA, R.G. 2. ed. Métodos em fitopatologia. Viçosa, MG: Editora UFV, 2016. p.207-223.

ROCHA, F.S. et al. Coloração de fitonematóides com corantes usados na indústria alimentícia brasileira. Nematologia Brasileira, v.29, p.293-297, 2005. Available from: <http://docentes.esalq.usp.br/sbn/ nbonline/ol\%20292/293-297\%20co.pdf>. Accessed: Jan. 3, 2017.

RYVARDEN, L. Genera of Polypores: Nomenclature and taxonomy. Oslo, Norway: Fungiflora, 1991, v. 5, 363p. (Series Synopsis Fungorum).

SANTANA, J.K.G.;et al. Coloração de esporos fúngicos com corantes artificiais usados na fabricação de sucos. In: CONGRESSO BRASILEIRO DE QUÍMICA, 57., 2017, Gramado, RS. Gramado: Associação Brasileira de Química, 2017. Available from: <http:// www.abq.org.br/cbq/2017/trabalhos/13/11610-24707.html>. Accessed: Dec. 20, 2017.

SINGH, R.L. et al. Enzymatic decolorization and degradation of azo dyes - A review. International Biodeterioration \& Biodegradation, v.104, p.21-31, 2015. Available from: <https:// sci-hub.tw/10.1016/j.ibiod.2015.04.027>. Accessed: Jan. 2, 2017. doi: 10.1016/j.ibiod.2015.04.027.

VIGNESH, R. et al. Iodine-glycerol as an alternative to lactophenol cotton blue for identification of fungal elements in clinical laboratory. Indian Journal of Medical Microbiology, v.31, p.93-94, 2013. Available from: <http://sci-hub.tw/10.4103/0255-0857.108752>. Accessed: Dec. 2, 2016. doi: 10.4103/0255-0857.108752. 